\title{
Pengaruh Pembangunan Kebudayaan terhadap Pembangunan Manusia di Indonesia
}

\author{
Isna Zuriatina \\ (Badan Pusat Statistik Provinsi Nusa Tenggara Barat; isna.zฺ@gmail.com)
}

\begin{abstract}
The diversity of Indonesian culture is a strong basic capital in development. The government has realized that cultural treasures in Indonesia are valuable assets. Cultural development is one of the government's efforts to improve the welfare and quality of human life in Indonesia. To measure the quality of human life, the Human Development Index (HDI) indicator is used, which explains how the population can access the results of development in obtaining income, health, education, and so on. The Cultural Development Index (CDI) is an instrument used to measure the achievements of cultural development performance, which consists of 7 dimensions, namely dimensions of cultural economy, education, socio-cultural resilience, cultural heritage, cultural expression, cultural literacy, and gender. To find out how much influence the CDI has on HDI in Indonesia, a simple linear regression statistical method is used. The result of this study illustrate that the CDI and HDI have a positive relationship, that is, the higher the CDI achievement, the higher the HDI achievement of a region. From the result of $\mathrm{R}$ Square shows that 40 percent of the HDI variable can be explained by the CDI variable, while the rest can be explained by other factors. Through a simple linear regression statistical analysis test found that every one percent increase in the CDI, will increase the HDI by 0.437 percent. This finding is expected to provide recommendations to the government regarding cultural-based national development. All development planning must also consider cultural development.
\end{abstract}

\section{Keywords: Culture, human development, quality of human life}

\begin{abstract}
Abstrak
Keberagaman budaya Indonesia merupakan modal dasar yang kuat dalam pembangunan. Pemerintah telah menyadari bahwa khazanah kebudayaan di Indonesia merupakan aset yang sangat berharga. Pembangunan kebudayaan merupakan salah satu upaya pemerintah dalam meningkatkan kesejahteraan dan kualitas hidup manusia di Indonesia. Untuk mengukur kualitas hidup manusia digunakan indikator Indeks Pembangunan Manusia (IPM), dimana indeks ini menjelaskan bagaimana penduduk dapat mengakses hasil pembangunan dalam memperoleh pendapatan, kesehatan, pendidikan, dan sebagainya. Indeks Pembangunan Kebudayaan (IPK) merupakan suatu instrumen yang digunakan untuk mengukur capaian kinerja pembangunan kebudayaan, yang terdiri dari 7 dimensi, yaitu dimensi ekonomi budaya, pendidikan, ketahanan sosial budaya, warisan budaya, ekspresi budaya, budaya literasi, dan gender. Untuk mengetahui seberapa besar pengaruh IPK terhadap IPM di Indonesia, digunakan metode statistik regresi linier sederhana. Hasil penelitian ini menggambarkan bahwa IPK dan IPM memiliki hubungan yang positif, yaitu semakin tinggi capaian IPK maka semakin tinggi pula
\end{abstract}


capaian IPM suatu daerah. Dari hasil $R$ Square menunjukkan bahwa sebesar 40 persen variabel IPM dapat dijelaskan oleh variabel IPK, sedangkan sisanya dapat dijelaskan oleh faktor lainnya. Melalui uji analisis statistik regresi linier sederhana didapatkan bahwa setiap kenaikan satu persen IPK, akan menaikkan IPM sebesar 0,437 persen. Temuan ini diharapkan dapat memberikan rekomendasi kepada pemerintah terkait pembangunan nasional berbasis kebudayaan. Segala perencanaan pembangunan harus juga mempertimbangkan pembangunan kebudayaan.

\section{Kata Kunci: Budaya, kualitas hidup manusia, pembangunan manusia}

\section{A. PENDAHULUAN}

Tujuan dari penelitian ini adalah untuk mengetahui apakah Indeks Pembangunan Kebudayaan mempengaruhi Indeks Pembangunan Manusia di Indonesia. Manfaat dari penelitian ini adalah dapat menjadi masukan atau rekomendasi untuk pemerintah dalam mengambil kebijakan pembangunan nasional.

Indonesia memiliki kekayaan budaya yang beragam dan tersebar di seluruh wilayah Indonesia dari Sabang hingga Merauke. Keberagaman budaya ini merupakan salah satu aset bangsa yang sangat berharga. Hal ini merupakan salah satu modal dasar pembangunan. Menurut Alhumami (2018), Indonesia memiliki modal budaya yang kuat yang dapat dijadikan modal dasar percepatan pembangunan nasional. Terdapat tiga negara di kawasan Asia yaitu Jepang, China, dan Korea Selatan yang dianggap telah berhasil melakukan akselerasi pembangunan sosial ekonomi berbasis kebudayaan dengan melakukan kapitalisasi atas nilai-nilai kebudayaan melalui proses modernisasi. Dengan mengacu ke ketiga negara tersebut, Indonesia juga dapat melakukan akselerasi pembangunan kebudayaan.

Fakta tersebut menunjukkan bahwa kebudayaan memiliki peranan penting dalam pembangunan. Pemerintah Indonesia juga terus menerus berupaya untuk 
meningkatkan pembangunan kebudayaan. UU No. 5 Tahun 2017 tentang Pemajuan Kebudayaan membawa udara yang segar dalam pembangunan kebudayaan. Menurut UU tersebut, pemajuan kebudayaan bertujuan untuk mengembangkan nilai-nilai luhur budaya bangsa, memperkaya keberagaman budaya, memperteguh persatuan dan kesatuan bangsa, mencerdaskan kehidupan bangsa, mewujudkan masyarakat madani, meningkatkan kesejahteraan rakyat, melestarikan warisan budaya bangsa, dan mempengaruhi arah perkembangan peradaban dunia, sehingga kebudayaan menjadi haluan pembangunan nasional (Hennida dkk, 2017; Melina, 2016).

Keberhasilan pembangunan nasional di Indonesia dapat diukur melalui kualitas hidup masyarakat Indonesia (Fitriyani dan Rasaili, 2016). Salah satu alat ukur yang dapat digunakan adalah Indeks Pembangunan Manusia (IPM). Pembangunan manusia diukur dengan menggunakan pendekatan tiga dimensi dasar manusia, yaitu umur panjang dan sehat, pengetahuan, dan standar hidup yang layak (BPS, 2019). Terdapat tiga dari 17 tujuan SDGs yang berhubungan dengan pembangunan manusia (BPS, 2018), yaitu 1) menjamin kehidupan yang sehat dan meningkatkan kesejahteraan penduduk di segala usia; 2) menjamin kualitas pendidikan yang adil dan inklusif serta meningkatkan kesempatan belajar seumur hidup untuk semua;dan 3) meningkatkan pertumbuhan ekonomi yang inklusif dan berkelanjutan, kesempatan kerja penuh dan produktif, serta pekerjaan yang layak untuk semua.

Penelitian serupa sudah pernah dilakukan tetapi tidak terkait dengan pembangunan budaya secara langsung. Penelitian sebelumnya menjelaskan bahwa budaya memiliki kontribusi terhadap pembangunan suatu negara (Hennida dkk, 
2017). Selain itu, ada juga penelitian yang menyebutkan nilai-nilai budaya sangat mempengaruhi pembangunan ekonomi (Asmin, 2018).

\section{B. TINJAUAN PUSTAKA}

Kebudayaan memiliki banyak definisi, salah satunya menurut Lowie (1937) kebudayaan merupakan segala sesuatu yang diperoleh seorang individu dari masyarakat, mencakup adat istiadat, norma-norma yang berlaku, kepercayaan, serta keahlian yang diperoleh bukan dari hasil kreativitas sendiri melainkan merupakan warisan masa lalu yang didapat baik melalui pendidikan formal maupun pendidikan informal.

Pengertian pembangunan menurut Ali (2009) pembangunan adalah semua upaya yang dilakukan dan direncanakan untuk melaksanakan perubahan yang memiliki tujuan utama untuk memperbaiki dan menaikkan taraf hidup, kesejahteraan, dan kualitas manusia. Menurut Inayatullah (1967), pembangunan adalah suatu arah perubahan yang lebih baik menuju ke pola masyarakat yang lebih baik dengan mengedepankan nilai-nilai kemanusiaan sehingga mampu membuat sekelompok masyarakat memiliki kendali yang lebih besar terhadap kondisi lingkungan sekitarnya dan membuat warganya menjadi lebih memiliki kontrol terhadap kehidupan diri sendiri.

Ide dasar pembangunan manusia adalah memposisikan manusia sebagai suatu aset bangsa dan dapat menciptakan pertumbuhan dalam bidang ekonomi, sosial, politik, budaya dan lingkungan yang mendorong peningkatan kesejahteraan masyarakat. Pemikiran tersebut menggambarkan tujuan utama dari pembangunan 
manusia, yaitu mampu menciptakan lingkungan yang memungkinkan bagi masyarakat untuk memiliki umur panjang, sehat dan menjalankan kehidupan yang produktif (Human Developmnet Report, 1990).

Budaya mempunyai peranan dalam pembangunan manusia Indonesia (Asmin, 2018). Indonesia dapat membangun bangsa sesuai dengan karakteristik budaya masing-masing (Melina, 2016). Indeks Pembangunan Kebudayaan (IPK) merupakan indeks yang mampu mengukur sejauh mana keberhasilan pembangunan secara menyeluruh (BPS, 2019). Indeks Pembangunan Manusia (IPM) merupakan indeks komposit yang digunakan untuk mengukur keberhasilan dalam upaya membangun kualitas hidup manusia (BPS, 2019).

\section{METODE}

Penelitian ini menggunakan metode kuantitatif. Metode statistik yang digunakan adalah teknik analisis deskriptif, diagram kartesius dan regresi linier sederhana. Menurut Sugiyono (2011), analisis deskriptif adalah statistik yang digunakan untuk menganalisis suatu data dengan cara mendeskripsikan atau menggambarkan data yang sudah dikumpulkan dengan apa adanya tanpa menambahkan atau membuat kesimpulan dari data tersebut. Analisis regresi sederhana adalah analisis statistik yang bertujuan meramalkan bagaimana keadaan (naik turunnya) variabel dependen, bila ada satu variabel independen sebagai prediktor (Sugiyono, 2011). Data yang diolah merupakan data Indeks Pembangunan Kebudayaan (IPK) dan Indeks Pembangunan Manusia (IPM) tahun 2018 di Indonesia yang bersumber dari Badan Pusat Statistik. Variabel IPK sebagai variabel bebas dan variabel IPM sebagai variabel tidak bebas. 
Beberapa penelitian juga menggunakan analisis regresi linier untuk mengetahui hubungan beberapa variabel (Muqorrobin, 2017; Rakhmawati dkk, 2019).

\section{HASIL DAN PEMBAHASAN}

Pelaksanaan pembangunan secara tidak langsung mengubah nilai-nilai yang ada di masyarakat (Wahyuni, 2016; Yunus, 2013). Perubahan nilai-nilai budaya ini dilakukan untuk mengikuti perkembangan dengan tetap menganut nilai-nilai dasar tetapi dilakukan penyesuaian-penyesuaian (Baharuddin, 2015; Bahrudin dkk, 2017). IPK tidak dimaksudkan untuk mengukur nilai budaya suatu daerah, melainkan untuk mengukur capaian kinerja pembangunan kebudayaan (BPS, 2019). IPK di Indonesia tahun 2018 mencapai 53,74, yang artinya bahwa pembangunan kebudayaan di Indonesia masih memerlukan usaha dan kerja sama dari berbagai pihak (Effendi, 2013; Anggorowati dan Sarmini, 2015; Rolitia dkk, 2016), baik pemerintah maupun masyarakat. Dengan kerja keras dan kerja sama yang baik dari berbagai pihak maka akan menghasilkan capaian yang optimal. Pembangunan budaya merupakan suatu perubahan yang terjadi di masyarakat untuk mencapai sebuah kemajuan (Melina, 2016). Provinsi DI Yogyakarta, Bali, dan Jawa Tengah berada di posisi tiga teratas. Hal ini membuktikan bahwa memang di daerah seperti DI Yogyakarta dan Bali tetap menjaga budaya lokal dan bangunan bersejarah tetapi terus mengikuti perkembangan yang ada (Permata, 2016; Soeroso dan Susuilo, 2008; Miharja, 2013; Suwardani, 2015). Berdasarkan Gambar 1, terlihat bahwa terdapat beberapa provinsi yang berada di atas rata-rata nasional. Sebaliknya, masih banyak provinsi yang memiliki IPK di bawah rata-rata nasional. Hal ini berarti bahwa sentralisasi pembangunan kebudayaan 
masih terfokus pada Indonesia bagian barat dan tengah, sementara itu untuk wilayah Indonesia timur masih mengalami ketertinggalan dan membutuhkan akselerasi pembangunan kebudayaan (BPS, 2019).

Gambar 1.

Indeks Pembangunan Kebudayaan Menurut Provinsi di Indonesia, Tahun 2018

ผ 웅 б

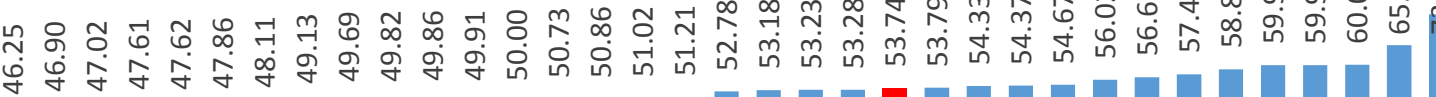
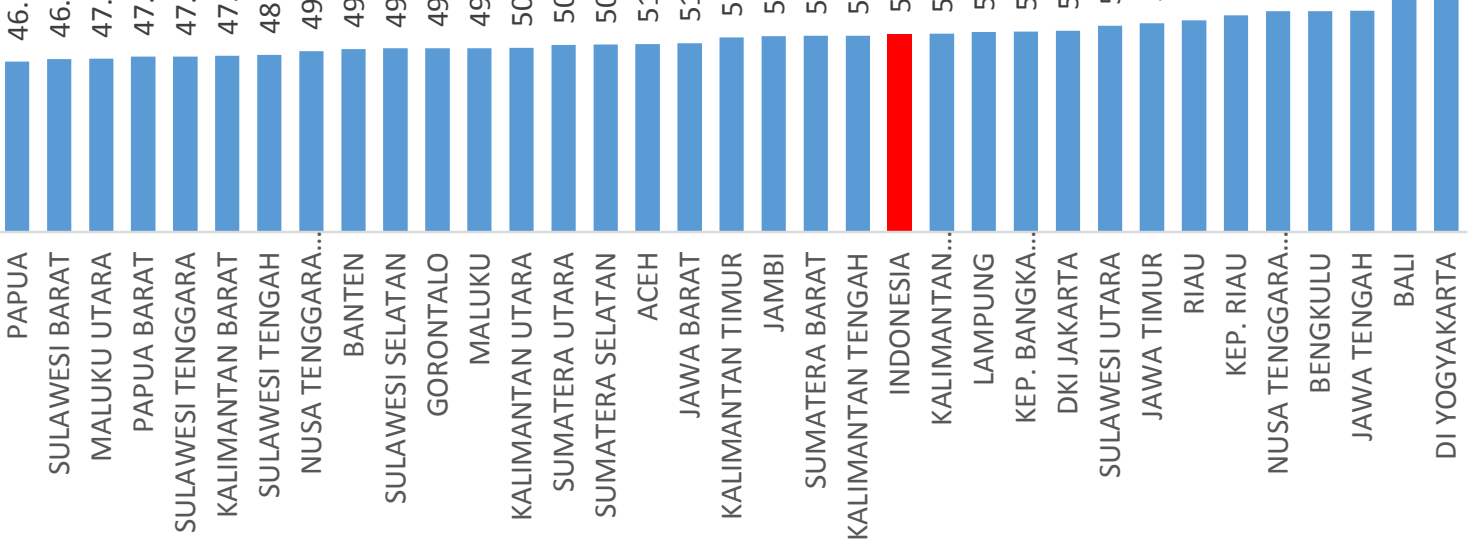

Semakin tinggi pertumbuhan ekonomi maka akan semakin meningkatkan IPM (Mirza, 2012). Pertumbuhan ekonomi di Indonesia tahun 1993-2016 berfluktuatif (Asbintari dkk, 2016). Berbeda halnya dengan IPM, selama kurun waktu 2010-2018 IPM Indonesia terus menerus mengalami peningkatan (BPS, 2019). Ini menunjukkan bahwa kualitas hidup masyarakat Indonesia mengalami perbaikan dari waktu ke waktu. Tahun 2018 IPM Indonesia mencapai 71,39, capaian ini merupakan ketiga kalinya Indonesia berstatus pembangunan manusia "tinggi". IPM dikelompokkan menjadi beberapa kategori, yaitu kategori rendah jika IPM $<60$; kategori sedang jika $60 \leq \mathrm{IPM}<70$; kategori tinggi jika $70 \leq \mathrm{IPM}<80$; dan kategori tinggi jika IPM $\geq 80$. 
Dilihat menurut provinsi, capaian IPM tertinggi berada di Provinsi DKI Jakarta dengan IPM sebesar 80,47, sedangkan capaian terendah berada pada Provinsi Papua dengan IPM sebesar 60,06. Dari 34 provinsi yang ada di Indonesia, hanya 9 provinsi yang berada di atas rata-rata nasional, yaitu Provinsi DKI Jakarta, DI Yogyakarta, Kalimantan Timur, Kepulauan Riau, Bali, Riau, Sulawesi Utara, Banten, dan Sumatera Barat. Masih terdapat 25 provinsi yang nilai IPM nya yang berada di bawah rata-rata nasional.

Gambar 2.

Indeks Pembangunan Manusia Menurut Provinsi di Indonesia, Tahun 2018

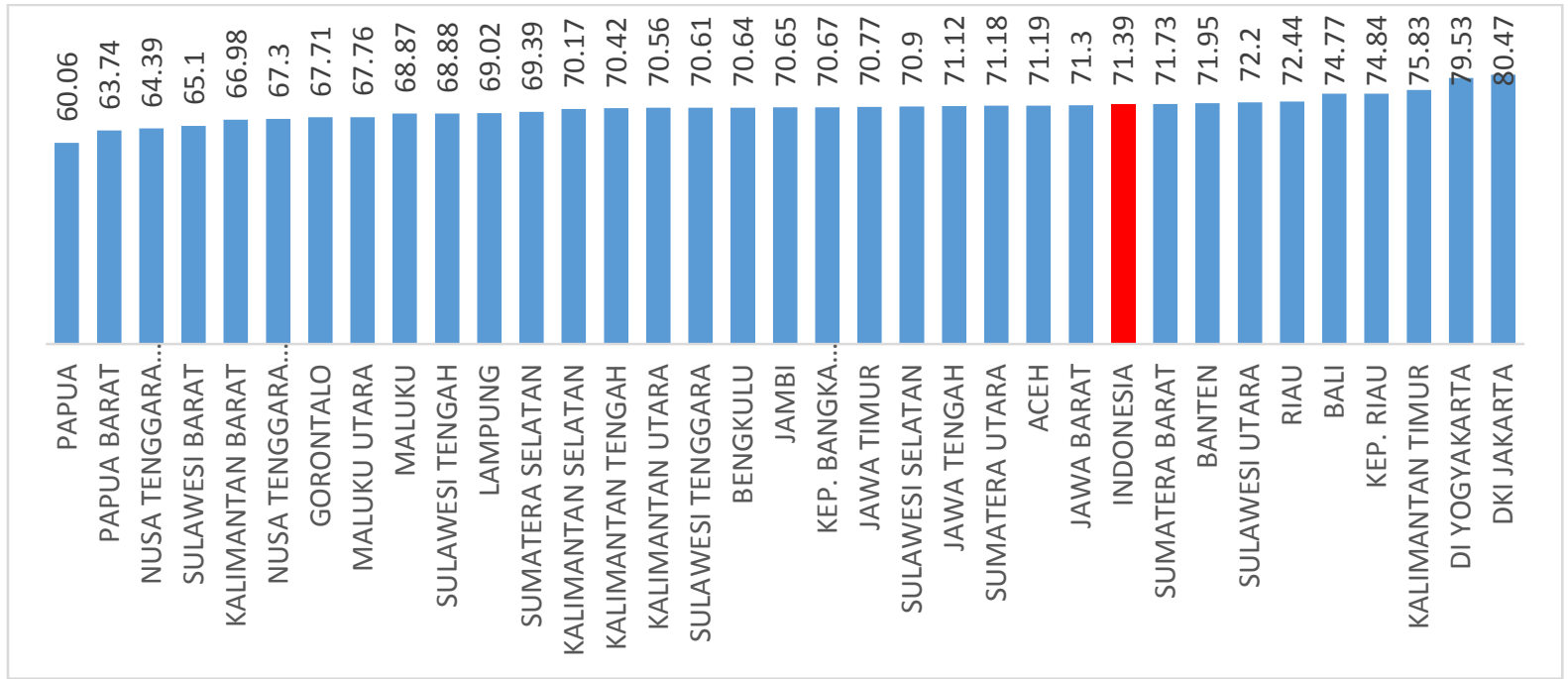

Diagram kartesius merupakan suatu bangun yang dibagi atas empat bagian yang dibatasi oleh dua buah garis yang berpotongan tegak lurus (Suharto, 2009). Gambar 3 menggambarkan bahwa terdapat 4 kuadran antara IPK dan IPM. Kuadran pertama, dimana nilai IPK dan IPM berada di bawah angka nasional. Kuadran kedua, IPK 
berada di atas angka nasional tetapi IPM berada di bawah nasional. Kuadran ketiga, IPK berada di bawah angka nasional dan IPM berada di atas nasional. Kuadran keempat, IPK dan IPM berada di atas angka nasional. Dari kuadran tersebut, terlihat bahwa masih banyak provinsi di Indonesia yang berada di kuadran pertama, dan hanya 6 provinsi yang berada di kuadran keempat. Provinsi tersebut adalah Sulawesi Utara, Riau, Kepulauan Riau, Bali, DKI Jakarta, dan DI Yogyakarta. Hanya terdapat empat provinsi yang berada di kuadran ketiga, yaitu Provinsi Jawa Barat, Sumatera Barat, Banten, dan Kalimantan Timur. Sebagian besar provinsi yang berada di kuadran pertama merupakan Indonesia di wilayah timur. Hal ini mengindikasikan bahwa pembangunan kebudayaan dan pembangunan manusia di wilayah timur mengalami ketertinggalan akselerasi pembangunan (Rosmeli dan Nurhayani, 2014). 
Gambar 3.

Indeks Pembangunan Kebudayaan dan Indeks Pembangunan Manusia Menurut Provinsi di Indonesia, Tahun 2018

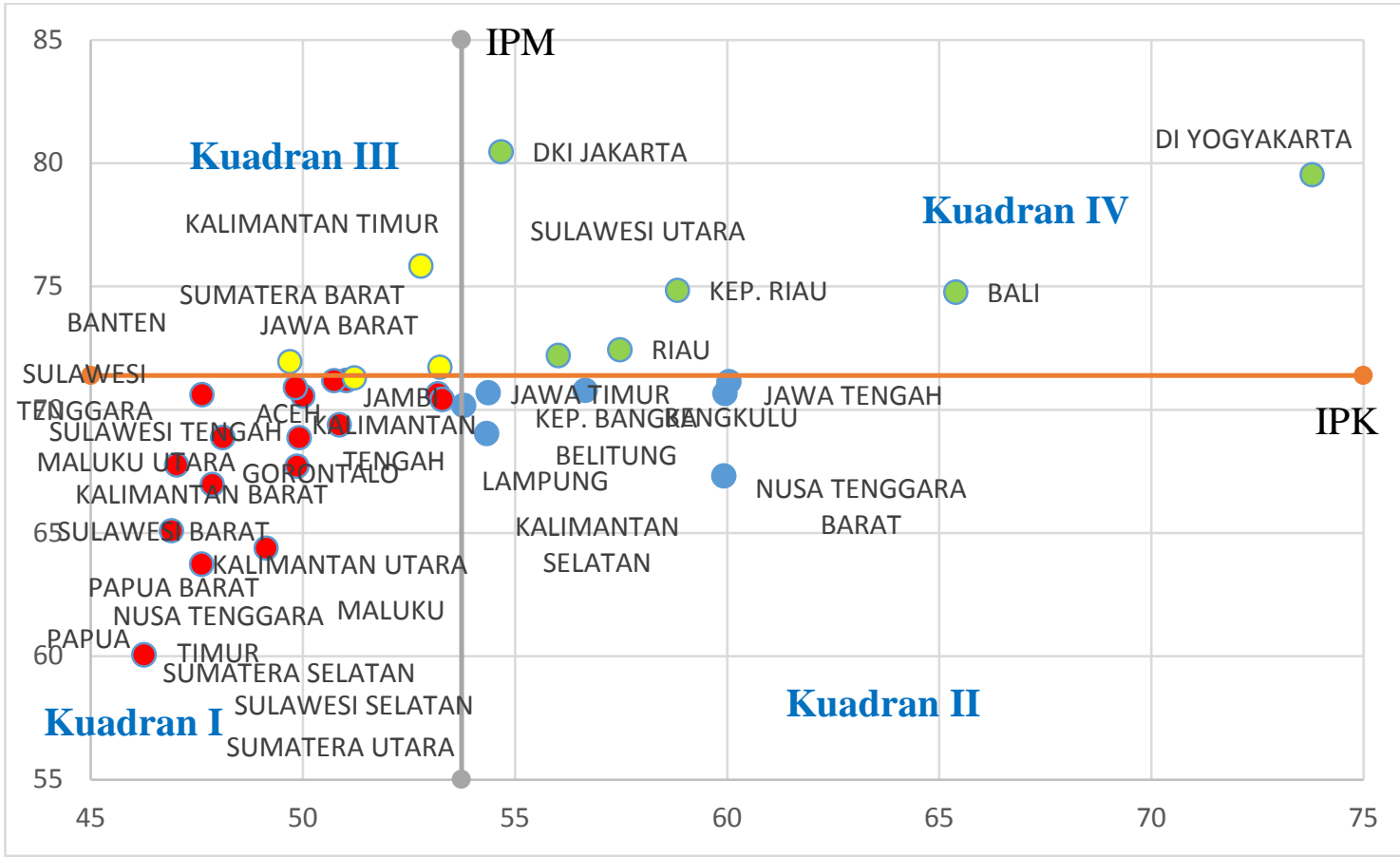

Perencanaan budaya seharusnya didesain untuk menghasilkan pembangunan budaya bukan pembangunan ekonomi (Harsasto, 2018). Setiap perencanaan pembangunan sebaiknya juga sebaiknya mempertimbangkan budaya. Nilai R Square pada Gambar 3 sebesar 0,406, yang artinya Indeks Pembangunan Kebudayaan dan Indeks Pembangunan Manusia memiliki hubungan yang sedang. Variabel bebas IPK memiliki pengaruh kontribusi sebesar 40,60 persen terhadap variable IPM, dan sisanya dipengaruhi oleh faktor-faktor lainnya. Persamaan yang diperoleh adalah $\mathrm{Y}=$ 47,12 + 0,437X, dimana X merupakan IPK dan Y adalah IPM. Dari persamaan tersebut dapat dirumuskan bahwa apabila IPK benilai 0 maka IPM akan bernilai 
47,12. Selain itu, model tersebut menggambarkan bahwa IPK dan IPM memiliki hubungan yang positif, setiap kenaikan 1 persen IPK akan meningkatkan 0,437 persen IPM.

\section{Model Summary}

\begin{tabular}{|l|r|r|r|r|}
\hline Model & \multicolumn{1}{|c|}{$\mathrm{R}$} & R Square & $\begin{array}{c}\text { Adjusted R } \\
\text { Square }\end{array}$ & Std. Error of \\
the Estimate
\end{tabular}

a. Predictors: (Constant), IPK

ANOVA $^{\mathrm{a}}$

\begin{tabular}{|c|c|c|c|c|c|}
\hline Model & $\begin{array}{l}\text { Sum of } \\
\text { Squares }\end{array}$ & $\mathrm{df}$ & Mean Square & $\mathrm{F}$ & Sig. \\
\hline $\begin{array}{l}\text { Regression } \\
\text { Residual } \\
\text { Total }\end{array}$ & $\begin{array}{l}213.868 \\
312.589 \\
526.457\end{array}$ & $\begin{array}{r}1 \\
32\end{array}$ & $\begin{array}{r}213.868 \\
9.768\end{array}$ & 21.894 & $.000^{\mathrm{b}}$ \\
\hline
\end{tabular}

a. Dependent Variable: IPM

b. Predictors: (Constant), IPK

\section{Coefficients $^{\mathrm{a}}$}

\begin{tabular}{|c|c|c|c|c|c|}
\hline Model & & ardized & $\begin{array}{l}\text { Standardized } \\
\text { Coefficients }\end{array}$ & $\mathrm{t}$ & Sig. \\
\hline & B & Std. Error & Beta & & \\
\hline
\end{tabular}




\begin{tabular}{|ll|r|r|r|r|r|}
\hline 1 & (Constant) & 47.117 & 5.002 & & 9.420 & .000 \\
& IPK & .437 & .093 & .637 & 4.679 & .000 \\
\hline
\end{tabular}

a. Dependent Variable: IPM

Model regresi linier sederhana yang diperoleh dapat digunakan untuk memprediksi variabel IPM di Indoensia. Variabel bebasnya adalah IPK yang memiliki hubungan positif terhadap IPM. Semakin tinggi IPK suatu daerah maka Semakin tinggi pula IPM daerah tersebut. Hal ini semakin memperkuat teori dan penelitian sebelumnya yang mengatakan bahwa kebudayaan berpengaruh besar terhadap pembangunan (Hennida dkk, 2017; Asmin, 2018).

Keterbatasan penelitian ini adalah variabel independen yang digunakan pada penelitian ini terbatas hanya pada satu variabel, yaitu IPK. Selain itu, penelitian ini juga terbatas hanya pada tahun 2018, dikarenakan BPS baru pertama kali merilis capaian pembangunan kebudayaan. Analisis yang digunakan juga cukup sederhana yaitu analisis regresi linier sederhana dan tidak dilakukan uji normalitas, linearitas, dan heteroskedastisitas.

\section{E. KESIMPULAN}

Hasil pengujian secara langsung dengan teknik regresi linier sederhana menunjukkan bahwa Indeks Pembangunan Kebudayaan (IPK) memiliki pengaruh yang positif terhadap Indeks Pembangunan Indonesia (IPM). Hal ini telah sesuai dengan penelitian sebelumnya. Semakin baik tingkat kebudayaan suatu daerah maka kesejahteraan masyarakat akan semakin meningkat. Temuan ini dapat memberikan 
rekomendasi kepada pemerintah terkait pembangunan nasional berbasis kebudayaan. Segala perencanaan pembangunan harus juga mempertimbangkan pembangunan kebudayaan.

\section{DAFTAR PUSTAKA}

Alhumami, A. (2018). Kebudayaan Bisa Jadi Modal Penggerak Pembangunan Manusia. Republika. Diakses pada 5 November 2019 melalui

bttps:// www.republika.co.id/berita/pendidikan/eduaction/18/08/01/pcrw2a335-kebudayaanbisa-jadi-modal-penggerak-pembangunan-nasional.

Ali, M. (2009). Pendidikan Untuk Pembangunan Nasional: Menuju Bangsa Indonesia Yang Mandiri Dan Berdaya Saing Tinggi. Grasindo.

Anggorowati, P., \& Sarmini, S. (2015). Pelaksanaan Gotong-Royong di Era Global (Studi Kasus di Desa Balun Kecamatan Turi Kabupaten Lamongan). Kajian Moral dan Kewarganegaraan, 1(3), 39-53.

Asbiantari, D. R., Hutagaol, M. P., \& Asmara, A. (2018). Pengaruh Ekspor Terhadap Pertumbuhan Ekonomi Indonesia.Jumal Ekonomi dan Kebijakan Pembangunan, 5(2).

Asmin, F. (2018). Budaya dan Pembangunan Ekonomi: Sebuah Kajian terhadap Artikel Chavoshbashi dan Kawan-Kawan. Jurnal Studi Komunikasi, 2(2).

Baharuddin, B. (2015). Bentuk-Bentuk Perubahan Sosial dan Kebudayaan. AlHikmah, 9(2). 
Bahrudin, B., Masrukhi, M., \& Atmaja, H. T. (2017). Pergeseran Budaya Lokal Remaja Suku Tengger di Desa Argosari Kecamatan Senduro Kabupaten Lumajang. Journal of Educational Social Studies, 6(1), 20-28.

BPS. (2018). Indikator Tujuan Pembangunan Berkelanjutan (TPB) Indonesia 2018. Jakarta: BPS.

BPS. (2019). Indeks Pembangunan Kebudayaan 2018. Jakarta: BPS.

BPS. (2019). Indeks Pembangunan Manusia 2018. Jakarta: BPS.

Effendi, T. N. (2013). Budaya Gotong Royong Masyarakat dalam Perubahan Sosial Saat Ini. Jurnal Pemikiran Sosiologi, 2(1), 1-17.

Fitriyani, M. W. W., \& Rasaili, W. (2016). Keberhasilan Pembangunan Kualitas Hidup Masyarakat Di Desa Karanganyar Kecamatan Kalianget. Public Corner, 10(2).

Harsasto, P. Pembangunan Berbasis Budaya Sebagai Strategi Pembangunan Kota: Revitalisasi Pasar Gede Di Kota Surakarta. Politika: Jurnal Ilmu Politik, 9(1), 3446.

Hennida, C., Felayati, R. A., Wijayanti, S. H., \& Perdana, A. R. (2017). Budaya dan Pembangunan Ekonomi di Jepang, Korea Selatan dan China. Global \& Strategis, 10(2), 248-263.

Inayatullah (1967). Towards a Non-Western Model of Development. Honolulu: East-West Center Press. 
Lowie, R.H. (1937). History of Ethnological Theory. New York: Farrar \& Rinehart,inc.

Melina, S. S., \& Hum, M. (2016). Peranan Budaya Dalam Pembangunan Manusia Indonesia. Jurnal Ilmiah “Dunia Ilmu” Vol, 2(4).

Miharja, D. (2013). Adat, Budaya dan Agama Lokal Studi Gerakan Ajeg Bali Agama Hindu Bali. Kalam, 7(1), 53-78.

Mirza, D. S. (2012). Pengaruh kemiskinan, pertumbuhan ekonomi, dan belanja modal terhadap indeks pembangunan manusia di Jawa Tengah tahun 20062009. Economics Development Analysis Journal, 1(2).

Muqorrobin, M. (2017). Pengaruh Indeks Pembangunan Manusia (IPM) terhadap Pertumbuhan Ekonomi Provinsi Jawa Timur.Jurnal Pendidikan Ekonomi (JUPE), 5(3).

Permata, D. (2016). Perlindungan Dan Pengelolaan Budaya Lokal Di Kota Yogyakarta. Kajian Hukum, 1(1).

Rakhmawati, M., Susongko, P., \& Rohman, M. S. (2019). Pengaruh Indeks Sosial Ekonomi Budaya (ESCS) dan Dukungan Guru terhadap Prestasi Belajar Matematika Siswa Indonesia Berdasarkan Survey PISA Tahun 2015. JPMP (Jumal Pendidikan MIPA Pancasakti), 3(1), 11-23.

RI. (2017). Undang-Undang Nomor 25 Tahun 2017 tentang Pemajuan Kebudayaan. Jakarta: Sekretariat Negara. 
Rolitia, M., Achdiani, Y., \& Eridiana, W. (2016). Nilai Gotong Royong Untuk Memperkuat Solidaritas Dalam Kehidupan Masyarakat Kampung Naga. SOSIETAS, 6(1).

Rosmeli, S. E., \& Nurhayani, S. E. (2014). Studi Komperatif Ketimpangan Wilayah Antara Kawasan Barat Indonesia dan Kawasan Timur Indonesia. Jurnal Manajemen Terapan dan Kenangan, 3(1).

Soeroso, A., \& Susuilo, Y. S. (2008). Strategi konservasi kebudayaan lokal Yogyakarta. Jurnal Manajemen Teori dan Terapan $\mid$ Journal of Theory and Applied Management, 1(2).

Sugiyono, P. (2011). Metodologi penelitian kuantitatif kualitatif dan R\&D. Alpabeta, Bandung.

Suharto, A. M. (2009). Customer Service dalam Bisnis Jasa Transportasi. Jakarta: PT Raja Grafindo Persada.

Suwardani, N. P. (2015). Pewarisan nilai-nilai kearifan lokal untuk memproteksi masyarakat Bali dari dampak negatif globalisasi. Jurnal Kajian Bali Journal of Bali Studies), 5(2).

UNDP. (1990). Human Development Index 1990. New York: Oxford University Press.

Wahyuni. (2016). Perubahan Sistem Nilai dan Budaya dalam Pembangunan. Makassar: UIN Alauddin Makassar. 
Yunus, R. (2013). Transformasi nilai-nilai budaya lokal sebagai upaya pembangunan karakter bangsa. Jurnal Penelitian Pendidikan, 13(1), 67-79. 